\title{
Study of degradation processes of metals used in some artworks from the cultural heritage of Andalusia, Spain( ${ }^{(*)}$
}

\author{
A. Duran*, **, L.K. Herrera*, M.C. Jiménez de Haro*, J.L. Pérez-Rodríguez* and A. Justo*
}

\begin{abstract}
The study of the alteration processes of metals, such as lead, bronze, iron and tin-mercury alloys, used in some of the most important chosen artefacts of Andalusian Cultural Heritage is the main objective of this paper. Hydrocerussite and cerussite were detected in lead seals stored in a hole of cardboard. Bronze is altered to atacamite by environmental contamination, which is also responsible for the formation of rust from iron. Corrosion of the tin-mercury surface of amalgam mirrors produces tin monoxide and tin dioxide and releases liquid mercury from the solid phase.
\end{abstract}

\section{Estudio de los procesos de degradación de metales empleados en obras del patrimonio cultural de Andalucía, España}

\begin{abstract}
Resumen
El estudio de los procesos de alteración de metales como plomo, bronce, hierro y aleaciones de estaño-mercurio empleados en algunas de las más importantes ornamentaciones elegidas del patrimonio cultural de Andalucía es el principal objetivo de este trabajo. Hidrocerusita y cerusita se detectaron en sellos de plomo almacenados en compartimentos de cartón. El bronce se altera a atacamita debido a la contaminación ambiental, factor que es también responsable de la formación de compuestos polvorientos a partir del hierro. La corrosión de la amalgama de estaño-mercurio de espejos antiguos produce óxidos de estaño y restos de mercurio líquido procedentes de la fase sólida.
\end{abstract}

Palabras clave Procesos de degradación; Plomo; Bronce; Hierro; Amalgama de estaño y mercurio.

\section{INTRODUCTION}

For millennia, humans have used metals to create both utilitarian and ornamental items. Most metallic items suffer some corrosion process over time, mainly because of oxidation by air. The corrosion products are oxides, hydroxides, sulphides, sulphates and carbonates depending upon the metals present and the environmental condition of the metals.

The use of metals for artefact construction has been known since antiquity ${ }^{[1}$ and 2$]$. Metals were used less extensively as support for paintings in ancient times, probably because they were highly valued for other purposes and were not available in large sheets or panels. Sheets were beaten out laboriously by hand. Methods for rolling metals were developed in the middle of the $16^{\text {th }}$ century.
Lead alloys were widely used in antiquity, especially in organ pipes, coins and lead seals manufacturing. Depending on the characteristic of the environment to which it is exposed, lead is quite reactive, forming sulphate, carbonate or hydroxicarbonate compounds. The presence of lead carbonate compounds is responsible for the unsightly, white and powdery "white rust" of lead and can be localised on the surface in the form of pits $^{[3]}$. The carboxylic acids, formic, propanoic, tannic and acetic acids, formed by cellulose hydrolysis from woods or paperboards used to store lead artefacts in museums, can convert the lead surface of artefacts in voluminous corrosion compounds, and in some cases, the artworks may be corroded in bulk through a progressive peeling of the corrosion layer ${ }^{[4-6]}$.

\footnotetext{
(•) Trabajo recibido el día 7 de julio de 2008 y aceptado en su forma final el día 3 de febrero de 2009.

* Materials Science Institute of Seville. CSIC-University of Seville. Avda. Americo Vespucio, No 49 . 41092 Seville, Spain

** Centre de Recherche et des Restauration des Musées de France-CNRS UMR 171, Palais du Louvre, Porte des Lions, 14 Quai François Mitterrand, 75001 Paris, France.
} 
Small iron artefacts may be converted to iron oxides. Even when environmental conditions are adverse, oxyhydroxide or hydroxide compounds can be formed in iron implements. The most common compound formed is goethite $(\mathrm{FeOOH})$, which gives the brown and dark reddish brown colours to monuments. In poorly drained areas, lepidocrocite, an isomer of goethite, has been frequently reported $^{[7]}$; it gives a bright orange colour. Akaganeite $(\beta-\mathrm{FeOOH})$ forms in the presence of chlorine. Other iron artifacts are better preserved and consist of pure iron with carbon inclusions and a red iron oxide surface coating that is believed to be goethite ${ }^{[2]}$.

Bronzes are used for the construction of different types of artworks, statues and monuments of cultural relevance, due to its high stability to environmental corrosion. The corrosion of bronze monuments has been studied by several researchers ${ }^{[8-13]}$. This interest is mainly due to the increasing awareness of modern air pollution damage to the physical cultural heritage.

The tin amalgam mirror was the most commonly used reflective coating from the $16^{\text {th }}$ century until the beginning of the $20^{\text {th }}[14$ and 15$]$. The Venetian mirror industry dominated the market until the middle of the seventeenth century. The Venetian mirrors were very small by modern standards, but they were much larger and brighter than earlier mirrors and were therefore extremely expensive. The mirrors were made by sliding glass over tin foil that was flooded with mercury. The two metals reacted, forming a layer of crystals ${ }^{[16]}$. In 1687, the French discovered a way to cast mirror glass by pouring molten glass onto a metal plate and rolling it flat with a metal cylinder. Production of the amalgam mirror continued to be a difficult and very time-consuming process, mainly because of the glass itself, which needed to be colourless, free of bubbles and thick enough to be ground and polished on both sides before coating. This process was necessary for both cast and blown glass. The application of amalgam backing required a large quantity of mercury, and the vapour made the work very hazardous ${ }^{[14,15}$ and $\left.17-19\right]$.

The study of the alteration processes of metals, such as lead, bronze (copper-tin alloy), iron and tinmercury amalgam, used in some of the most important monuments of Andalusian Cultural Heritage, is the main objective of this paper. A series of case studies is presented to demonstrate the determination of the chemical composition of the degradation products of metals in different environments.

\section{MATERIALS AND EXPERIMENTAL METHODS}

\subsection{Materials}

The metals chosen for inclusion in this work were selected because they show general and exampled degradation processes.

Seville City Hall has an important lead seals collection. Part of the collection is stored in holes made in cardboard in a wood drawer that remains closed for a long time without adequate control of environmental conditions. The seals were manufactured with lead showing a "white rust" of lead due to an alteration process (Fig. 1a)). Samples of the seal powder, wood and cardboard were taken for the study.

Several samples taken from iron artefacts have been studied. Three samples have been selected for this work: hammered nails from the windchest of the baroque organ in San Lorenzo Church (Cadiz, Andalusia) (Fig. 1b)) and nails from the Portico in the Mosque Cathedral in Cordoba. The third sample was in the false arm of the Saint Paul ceramic figure of the Portico of Seville Cathedral.

Altered samples of bronze were taken from the Christ of Seville Cemetery (Fig. 1c)).

Samples were taken from several baroque mirrors from the $18^{\text {th }}$ century from different historical buildings in Granada (Andalusia). The samples selected for this work have different corrosion levels. One of these mirrors is shown in figure $1 \mathrm{~d}$ ).

\subsection{Experimental methods}

The crystalline phases were characterized by X-ray diffraction (XRD) using a Siemens diffractometer (model: kristalloflex D-5000). For the iron artefacts, a qualitative analysis of the crystalline phases on the surface based utilizing XRD in a grazing incidence mode (GID) was performed. GID uses a fixed low incidence angle and parallel beam optics to increase the path length through the corroded surface and decreases the X-ray penetration into the bulk ${ }^{[19]}$.

Samples were photographed with a digital camera (Nikon COOLPIX 4500) coupled to an optical microscope (Nikon HOPTIPHOT) with objectives x25, x50, x100 and x200, and electron microscopes (Jeol JSM5400 and HITACHI S-4800). Elemental chemical analyses were performed using a Jeol JSM5400 scanning electron microscope, which was equipped with an X-ray dispersive energy analyser (EDX). 
STUDY OF DEGRADATION PROCESSES OF METALS USED IN SOME ARTWORKS FROM THE CULTURAL HERITAGE OF ANDALUSIA, SPAIN ESTUDIO DE LOS PROCESOS DE DEGRADACIÓN DE METALES EMPLEADOS EN OBRAS DEL PATRIMONIO CULTURAL DE ANDALUCÍA, ESPAÑA
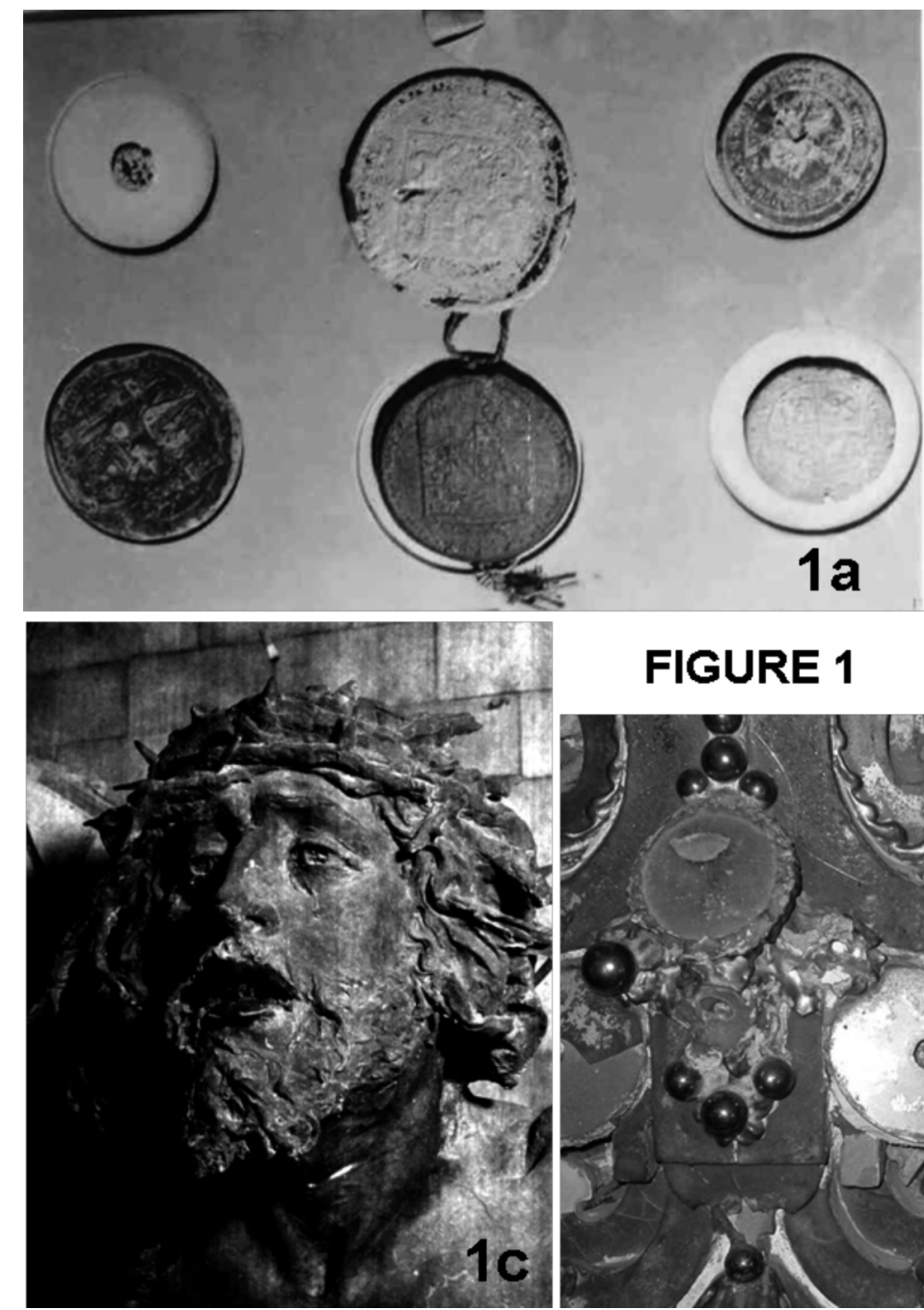

FIGURE 1

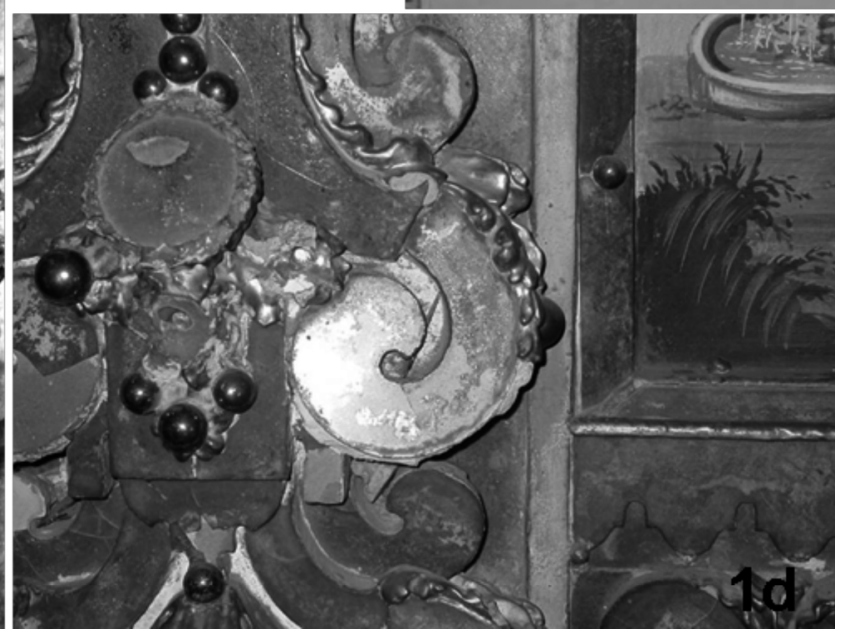

Figure 1. Photographs: a) lead seals from the Seville City Hall collection; b) hammered nails from the windchest of the Baroque organ in San Lorenzo Church (Cadiz); c) Christ of Seville Cemetery; d) Baroque mirrors from one of the historical buildings of Granada.

Figura 1. Fotografías: a) Colección de sellos de plomo del Ayuntamiento de Sevilla; b) Remachespuntillas del portavientos del órgano barroco en la Iglesia de San Lorenzo (Cádiz); c) Cristo del Cementerio de Sevilla; d) Espejos barrocos de uno de los edificios históricos de Granada.

\section{EXPERIMENTAL DATA AND DISCUSSION}

\subsection{Lead}

The analysis by SEM-EDX of the lead seals from Seville City Hall shows the presence of lead only (Fig. 2 a)).

Lead seals were stored in a wooden drawer inside a hole made in paperboard, at variable temperatures between $5^{\circ}$ and $38^{\circ}$, depending on the season, and relative humidity values normally higher than 85 $\%$. The morphological studies of fibres and wood were conducted using optical and scanning electron microscopy and comparison with standards. A cross section of the wood shows that the drawer was manufactured from pine (Figs. $3 \mathrm{a}$ ) and b)). The paperboard was composed of a mixture of fibres (vegetables and synthetic) ${ }^{[20-22]}$ (Figs. $3 \mathrm{c}$ ) and d)). We suggest that the alteration in the lead might be due to the storage of the seals in enclosures at the museum for a long period. The hydrolysis of the cellulose from the wood drawer and the paperboard contributed to the formation of carboxylic acid (mainly formic and acetic acids), which dissolves the $\mathrm{PbO}$ on the surface and forms lead carbonates ${ }^{[4,5,21}$ and $\left.23-25\right]$.

Lead seals belonging to the Sevillian collection had suffered significant alteration processes, losing not 


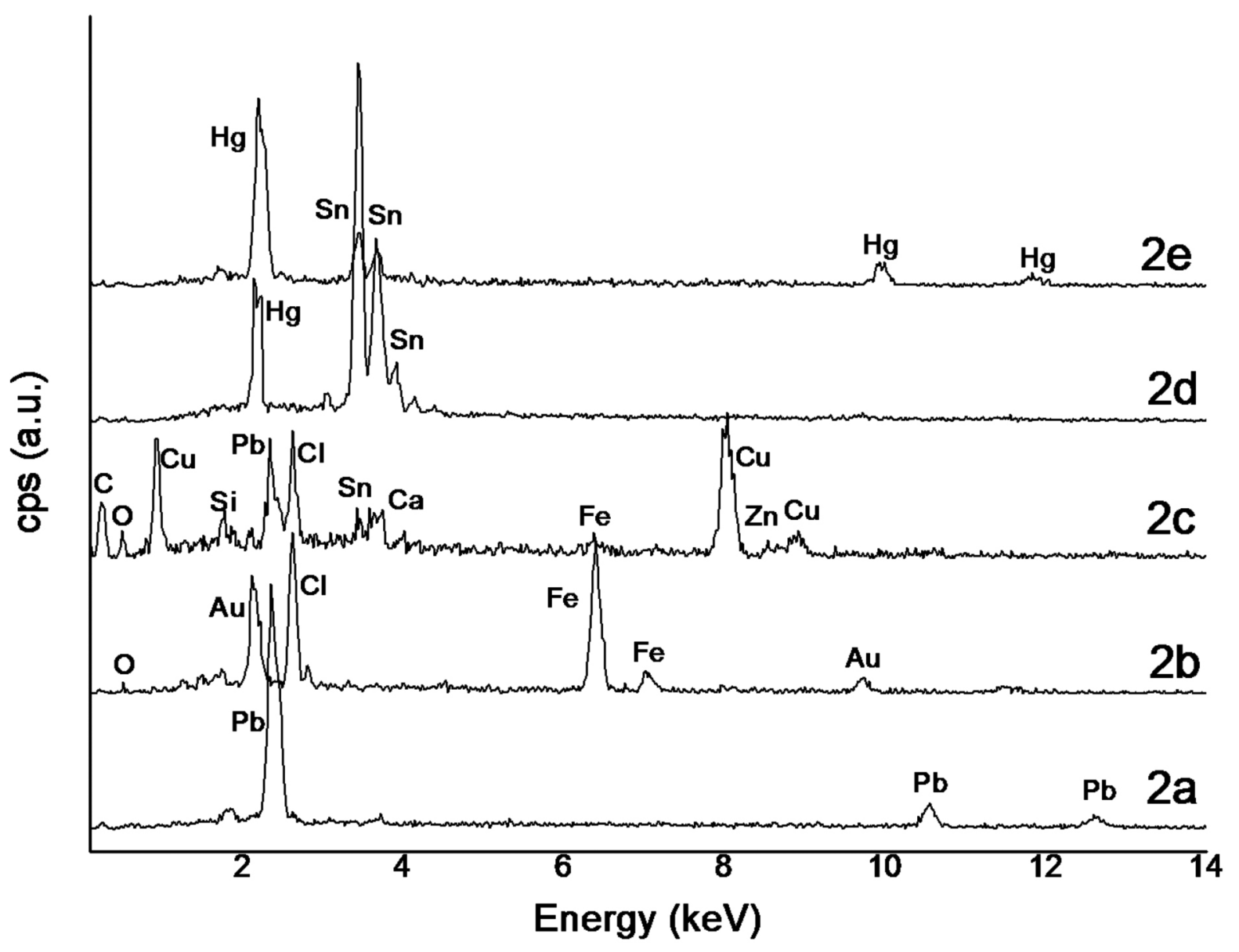

Figure 2. EDX analysis of: a) the lead seals in the Seville City Hall collection; b) nails from the Baroque organ in Cadiz; c) altered samples from the Christ of Seville Cemetery; d) the tin-mercury amalgam layer of the original mirror from one of Granada's buildings; e) liquid mercury, detected at the surface of the amalgam mirror.

Figura 2. Análisis por energías dispersivas de rayos $X$ de: a) Los sellos de plomo de la colección del Ayuntamiento de Sevilla; b) Remaches-puntillas del órgano barroco de Cádiz; c) Muestra alterada del Cristo del Cementerio de Sevilla; d) La amalgama de estaño-mercurio original de un espejo de Granada; e) Mercurio líquido, detectado en la superficie de la amalgama del espejo.

only the external figurative prominence, but some of them were also corroded in bulk through a progressive peeling of the corrosion layer. This represents an alteration of the entire sample and shows the powdery "white rust" of lead. X-ray diffraction of the powdery material (Fig. 3 e)) shows that it is composed of hydrocerussite $\left[\mathrm{Pb}_{3}\left(\mathrm{CO}_{3}\right)_{2}(\mathrm{OH})_{2}\right]$ and cerussite $\left[\mathrm{PbCO}_{3}\right]$. We suggest that this alteration process can be due to the effect of the carboxylic acids produced by the hydrolysis of the paperboard and wood that are used for storing the seals.

To evaluate the validity of this suggestion, the following experiment was performed in the lab, at room temperature and relative humidity values close to $100 \%$. In a beaker, a piece of paperboard was introduced together with a piece of lead. The beaker also contained water and $\mathrm{CO}_{2}$ separated from the paperboard and lead. After several months, the stored lead piece was covered with a white powder that the $\mathrm{x}$-ray diffraction confirms to be hydrocerussite and cerussite. The same experiment was repeated without using paperboard, and in this case, only lead oxide was formed on the surface. Thus, the laboratory experiment clearly shows the role of the paperboard in the corrosion process.

This degradation process is ratified by the studies by Bradey and Thicket ${ }^{[26]}$ and Raychaudghuri and Brumblecombe ${ }^{[27]}$. The effects of compounds such as acetic acid, formic acid and formaldehyde on lead were investigated at room temperature. At $100 \%$ RH after 120 days, the acetic acid had caused complete corrosion, and formic acid had caused 

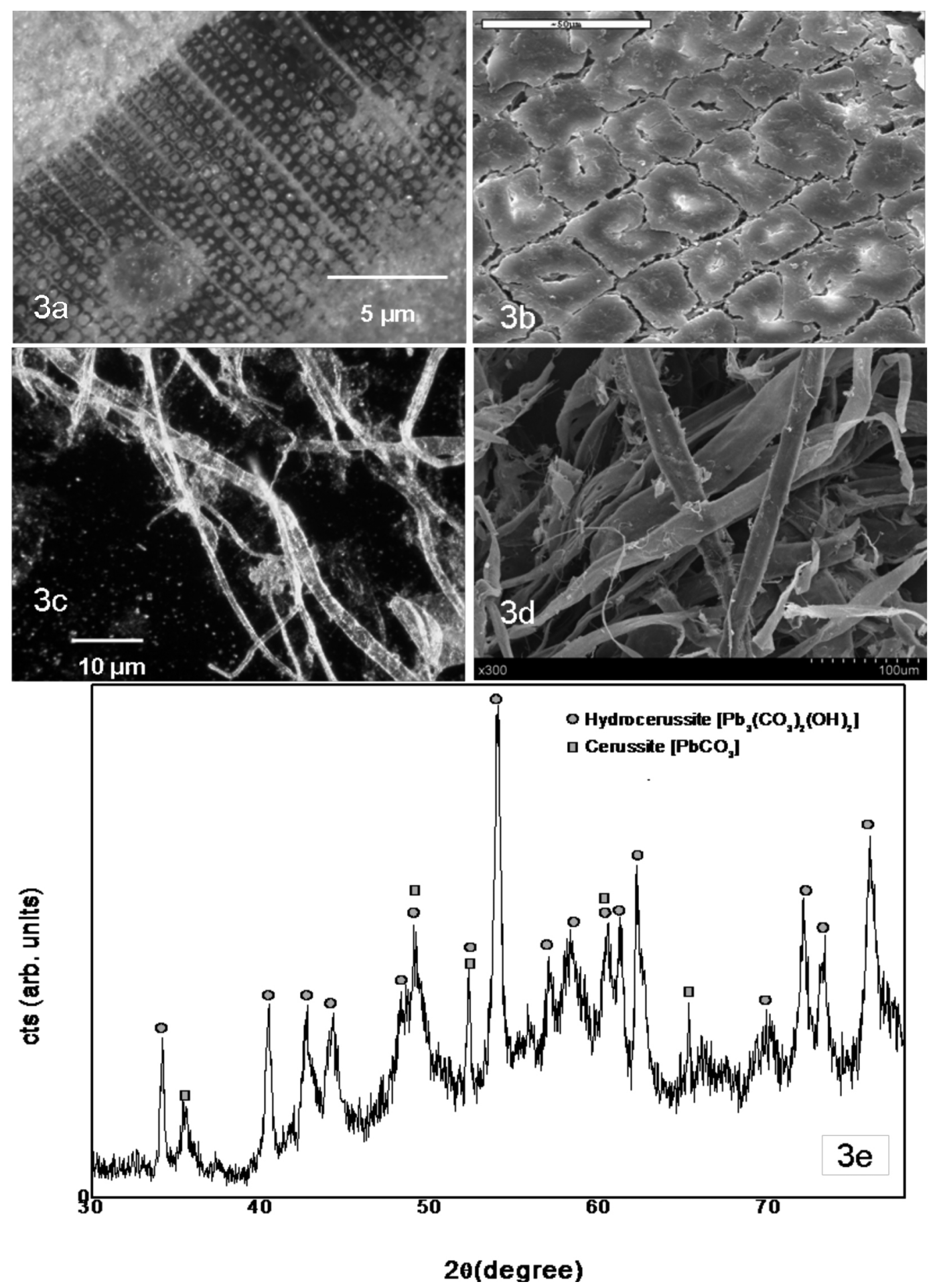

Figure 3. a) Optical microscopy image of the cross section of the drawer wood; b) scanning electron microscopy image of the transversal cross section of the drawer wood; c) optical microscopy image of the fibers from paperboard; d) scanning electron microscopy image of the fibers from paperboard;e) X-ray diffraction diagram of powdery materials of lead seals [0 Hydrocerussite, $\mathbf{c}$ Cerussite].

Figura 3. a) Imagen de microscopio óptico de la sección transversal de la madera del contenedor; b) Imagen de microscopio electrónico de barrido de la sección transversal de la madera del contenedor; c) Imagen de microscopio óptico de las fibras del cartón; d) Imagen de microscopio electrónico de barrido de las fibras del cartón; e) Diagrama de difracción de rayos $X$ del material pulverulento de los sellos de plomo [0 Hidrocerusita, $\mathbf{0}$ Cerusita]. 
extensive corrosion; formaldehyde had caused the least corrosion. At $50 \% \mathrm{RH}$ acetic acid and formic acid were less corrosive than at $100 \% \mathrm{RH}$, and formaldehyde did not cause any corrosion. Although acetic acid was detected at $30 \% \mathrm{RH}$, at all temperatures no corrosion of the lead pieces occurred. These experiments suggest that, as we thought, acetic and formic acids (in our case coming from paperboard), in conditions of high relative humidity, cause major lead artefact deterioration.

\subsection{Iron}

The study of the influence of atmospheric corrosion of iron artefacts at two sites, outdoors and indoors, under different exposure conditions (urban and coastal), is reported. Sulphur and chloride ions are the most common and important atmospheric corrosion agents.

The XRD of the corroded surface of nails from the Baroque organ in Cadiz (coastal indoor) shows akaganeite $[\beta-\mathrm{FeOOH}]$ phase, which is a common oxyhydroxide that forms in presence of chlorine ${ }^{[28]}$ (Fig. 4 a)). Akaganeite frequently appears in monuments located at the seaside and in archaeological sites where chlorine is present in the environment. EDX analysis confirms the presence of $\mathrm{O}, \mathrm{Fe}$, and $\mathrm{Cl}$ on the rust surface of the organ nail (Fig. 2 b)).

The XRD pattern of the iron sample from the Portico of Seville Cathedral (urban outdoors) shows

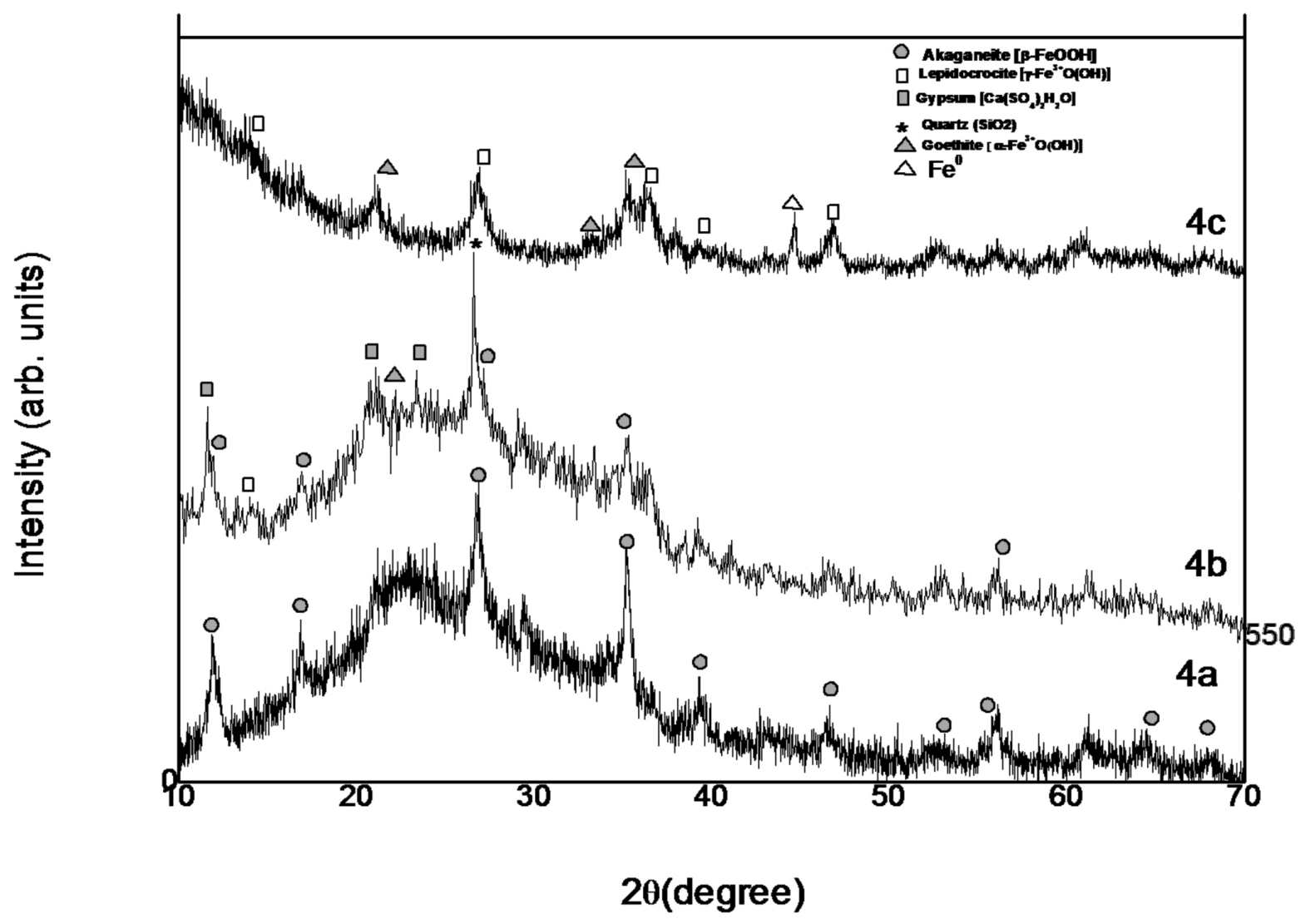

Figure 4. Grazing incidence X-ray diffraction diagrams of: a) the corroded surface of nails from the Baroque organ in Cadiz; b) the altered material of nails of Pardon Portico in Mosque-Cathedral of Cordoba; c) iron sample from Portico of Seville Cathedral [ $\bullet$ akaganeite, $\square$ lepidocrocite, $\boldsymbol{\square}$ gypsum, ${ }^{*}$ quartz, $\triangle$ goethite, $\left.\triangle \mathrm{Fe}^{0}\right]$.

Figura 4. Diagramas de difracción de rayos $X$ en ángulo rasante correspondientes a: a) La superficie corroída y alterada de las puntillas-remaches del órgano barroco de Cádiz; b) Material alterado de puntillas-remaches del Pórtico del Perdón de la Mezquita-Catedral de Córdoba; c) Muestra de hierro procedente del Pórtico de la Catedral de Sevilla [- akaganeita, $\square$ lepidocrocita, $\mathbf{\square}$ yeso, * cuarzo, $\triangle$ goetita, $\triangle \mathrm{Fe}^{0}$. 
the presence of lepidocrocite $\left[\gamma-\mathrm{Fe}^{3+} \mathrm{O}(\mathrm{OH})\right]$ and goethite $\left.\left[\alpha-\mathrm{Fe}^{3+} \mathrm{O}(\mathrm{OH})\right](\mathrm{Fig} .4 \mathrm{c})\right)$. Theses crystalline phases are formed due to adverse environmental conditions, which produce an increase of highly reactive and oxidizing substances.

In the third case, however, akaganeite was found in the nails from the Portico in the Mosque Cathedral of Cordoba, which is located in an urban outdoor environment. The presence of akaganeite has been attributed to an incorrect cleaning procedure with an inappropriate product containing chlorine (Fig. $4 \mathrm{~b}))^{[29]}$. Although there is a large distance between Cordoba and the coast, the presence of chloride ions from the sea could not be discounted, but in this case, the presence of akaganeite is attributed to a cleaning product, based on the testimonies and studies of different restorers, who performed a partial restoration in this Portico. In this corroded surface, goethite $[\alpha-$ $\left.\mathrm{Fe}^{3+} \mathrm{O}(\mathrm{OH})\right]$, lepidocrocite $\left[\gamma-\mathrm{Fe}^{3+} \mathrm{O}(\mathrm{OH})\right]$, gypsum $\left[\mathrm{Ca}\left(\mathrm{SO}_{4}\right) 2 \mathrm{H}_{2} \mathrm{O}\right]$ and quartz $\left(\mathrm{SiO}_{2}\right)$ also appear.

Comparing our case with others found in the literature ${ }^{[30}$ and 31$]$, iron artefacts collected in elements of ancient monuments present ancient rust layers formed during their exposure to the indoor atmosphere. Goethite and lepidocrocite are the main phases, often correlated with cracks. $\mathrm{Cl}$-containing phases, such as akagenite, appear even when the $\mathrm{Cl}$ level or concentration is low, as happens in seaside environments and artefacts buried in soil, leading to serious problems for the conservation of metallic objects of cultural heritage.

\subsection{Bronze}

The degradation of statues, as a result of corrosion, has resulted in regions becoming essentially black and others ranging through various shades of green, as observed in the Christ sculpture studied. Different factors, such as the accumulation of different kinds of aerosols, the increasing presence of traces of heavy metals with strong catalytic properties, residues from vehicles, the increase of highly reactive and oxidizing substances, such as non-metallic oxides and ozone, contribute to unidentified decay mechanisms of bronzes, which are more complex and more varied ${ }^{[32]}$.

The chemical examination of the corrosion of copper and bronze artefacts has been the subject of study for at least 150 years. Bronze disease is to bronze metals, what rust is to iron based metals; the matrix of copper and tin is attacked by hydrochloric acid to form tin chloride and copper. The most probable cause concerning the origin of bronze disease is the slow action of gaseous pollutants in showcases constructed of unsuitable materials that evolve sulphurous contaminants ${ }^{[33]}$. The best-known early attempt to deal with the problem of bronze disease is that of Berthelot, in $1895^{\text {[34] }}$, who reported some of his proposals to account for the instability of certain bronzes. He recognized that there must be an important cyclical component to the reaction. He also realized that one of the important products of the reaction was the basic copper chloride, atacamite, which at that time was assigned the formula $3 \mathrm{CuO}, \mathrm{CuCl}_{2}, 4 \mathrm{H}_{2} \mathrm{O}$. Objects studied by $\mathrm{Scott}^{[35]}$ show considerable variation in the extent to which surface disruption occurs with time. A number of bronze objects from Palestine are in the Petrie Collection, Department of Western Asia, University College, London. One of these objects, which had obviously suffered severe bronze disease and had been stored in uncontrolled conditions for more than 20 years, was examined and analyzed. The light green corrosion was identified as a mixture of atacamite and paratacamite, the most commonly found mixture of isomers in many ancient bronzes regardless of the location in which they were found. Most of the small objects in this collection illustrate the effects of disintegration in poor storage conditions over many decades.

The Christ of Sevillian Cemetery is situated indoors. A sample taken from the sculpture is not representative of the entire figure, and it is much altered (the possibility of collecting samples was very limited in this case). This sample shows a composition based on copper and tin, as shown in analysis by SEM-EDX, although lead and zinc are also observed. The presence of these heavy metals with strong catalytic properties possibly contributed to the deterioration processes (Fig. 2 c)). In industrial atmospheres (mainly fertiliser industries), copper chloride compounds are formed. In this form, the altered samples taken from the Christ are composed mainly of atacamite $\left[\mathrm{Cu}_{2} \mathrm{Cl}(\mathrm{OH})_{3}\right]$ and not of cuprous chloride, according to the XRD powder study (figure not shown). Cuprous chlorides are very unstable mineral compounds and occurrences of atacamite are evidence in conditions of low $\mathrm{CuCl}_{2}$ concentration and high relative humidity values and oxygen amounts ${ }^{[36}$ and 37$]$, conditions commonly found around studied Christ statue, situated outdoors and with relative humidity values close to $80 \%$ during some months in the year.

\subsection{Tin amalgam mirrors}

In the non corroded sample, the elemental composition by EDX shows that is composed of $\mathrm{Sn}$ and $\mathrm{Hg}$ (Fig. 2 d)). The XRD patterns show the presence of $\mathrm{Hg} 0.1 \mathrm{Sn} 0.9$ and metallic tin (Fig. 5 a)); 


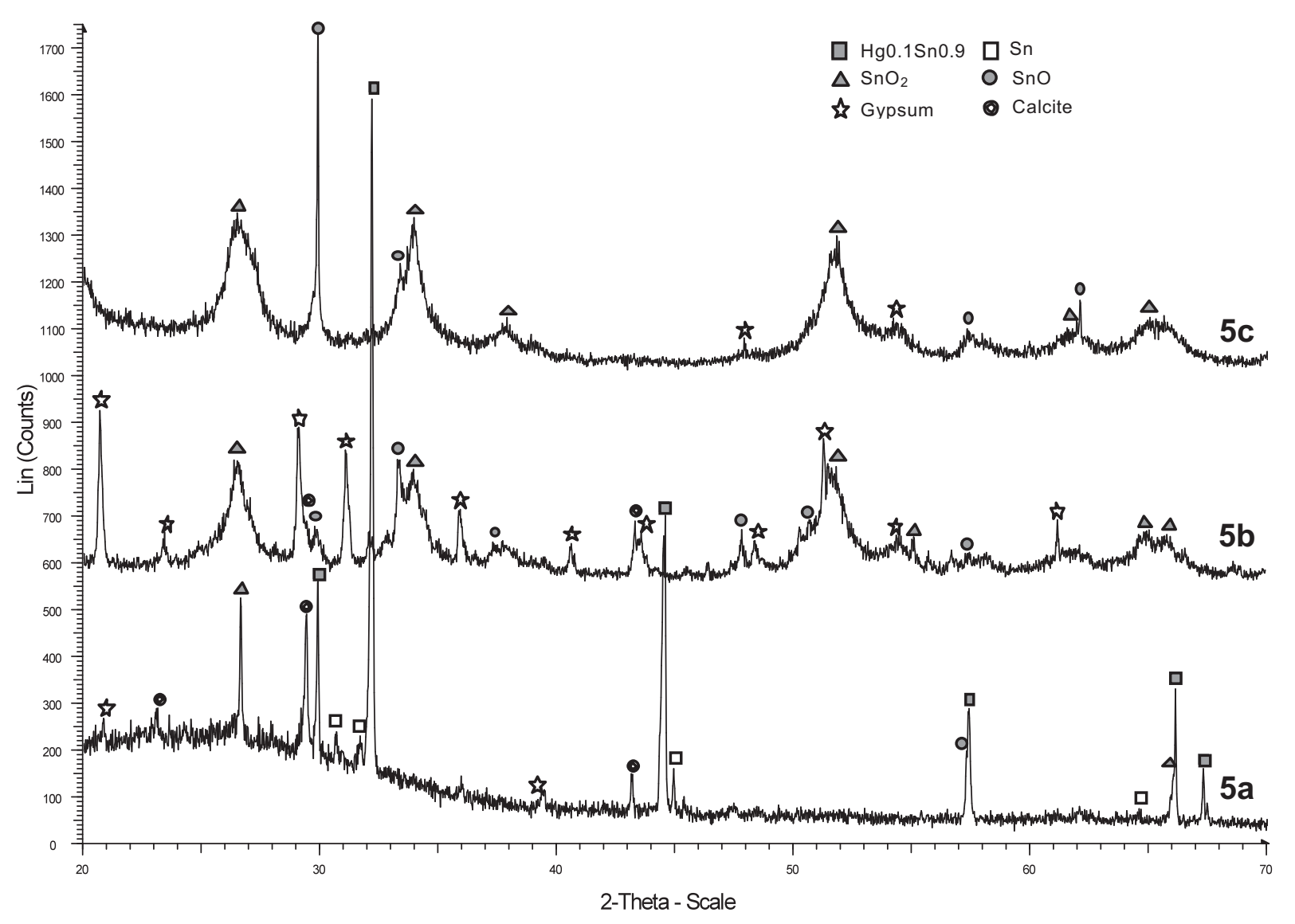

Figure 5. (a) (b) (c) Diffraction patterns of the different levels of corrosion from amalgam mirrors from Andalusia buildings (in Granada) [ $\mathrm{Hg} 0.1 \mathrm{Sn} 0.9, \square \mathrm{Sn}, \bullet \mathrm{SnO}, \boldsymbol{\Delta} \mathrm{SnO}_{2}$, is Gypsum, (O) Calcite].

Figura 5. (a) (b) (c) Diagramas de difracción de rayos $X$ de los diferentes niveles de alteración en la amalgama de espejos procedentes de los edificios históricos andaluces (en Granada) [ $\mathrm{Hg} 0.1 \mathrm{SnO}$.9, $\square \mathrm{Sn}, \bullet \mathrm{SnO}, \boldsymbol{\Delta} \mathrm{SnO}_{2}$, is Gypsum, (0) Calcite].

these results confirm that the original material was tin mercury amalgam.

The XRD patterns of the altered tin amalgam mirror show tin oxide, as mainly tin dioxide $\left[\mathrm{SnO}_{2}\right]$ and tin monoxide [SnO] (Fig. 5 b)). The most degraded tin amalgam mirror shows mainly the presence of $\mathrm{SnO}_{2}$ (Fig. 5 c)). In both altered samples, liquid mercury is detected by EDX only at the surface of the tin amalgam mirror (Fig. 2 e)). The lack of presence of [Hg0.1Sn0.9] in both sample mirrors suggests a high degree of degradation for the amalgam. Gypsum $\left[\mathrm{CaSO}_{4}\right]$ and calcite $\left[\mathrm{CaCO}_{3}\right]$ were present in some altered samples due to the situation of the mirror close to a polychrome altarpiece (Fig. 5 c)). According to these results, the tin amalgam mirrors studied in this work show a similar corrosion process, which is the oxidation of tin in the following way:

$$
\mathrm{Sn}^{0} \rightarrow \mathrm{Sn}^{2+} \rightarrow \mathrm{Sn}^{4+}
$$

The original material only shows the presence of $\mathrm{Sn}^{0}$. The corroded sample shows the presence of a mixture of $\mathrm{Sn}^{2+}$ and $\mathrm{Sn}^{4+}$. In the most corroded sample, mainly $\mathrm{Sn}^{4+}$ was detected. Mercury evaporation is closely related to the corrosion state of the tin amalgam mirror ${ }^{[38]}$.

The mercury-rich liquid phase present in these samples accelerated the corrosion of the tin-rich solid phase due to the de-alloying process and involves the selective leaching of mercury that slowly evaporates. Gravity could also have played a role in the formation and release of mercury drops. These facts are responsible for the presence of the liquid mercury phase on the top surface of the tin amalgam mirrors.

\section{CONCLUSIONS}

Metals used in several chosen monuments of Andalusian Cultural Heritage have suffered varying 
STUDY OF DEGRADATION PROCESSES OF METALS USED IN SOME ARTWORKS FROM THE CULTURAL HERITAGE OF ANDALUSIA, SPAIN ESTUDIO DE LOS PROCESOS DE DEGRADACIÓN DE METALES EMPLEADOS EN OBRAS DEL PATRIMONIO CULTURAL DE ANDALUCÍA, ESPAÑA

degrees of alteration due to the different environmental conditions. This work shows example cases of the degradation of these metals. All the cases have been compared with similar processes found in the literature, showing almost comparable results.

Cellulose hydrolysis from the paperboard and wooden drawers provided carboxylic acid that dissolves the $\mathrm{PbO}$ formed on the surface of lead seals in the Seville City Hall collection, forming lead carbonates.

Iron artefacts are altered to akaganeite in seaside environments and lepidocrocite and goethite in urban environments. Akaganeite was also found in one case due to an incorrect cleaning procedure.

Alteration to atacamite was observed in the Christ of Seville Cemetery, which was attributed to environmental contamination.

The tin amalgam mirror used in Baroque style mirrors is composed of a binary alloy of tin and mercury. This liquid mercury is volatile and slowly evaporates, leaving fine tin particles that oxidize easily, forming tin monoxide $(\mathrm{SnO})$ and tin dioxide $\left(\mathrm{SnO}_{2}\right)$. The mercury-rich phase accelerates the corrosion of the tin-rich phase.

\section{Acknowledgements}

This work was supported by the fellowship MEC/FULBRIGHT conferred by the Education, Science and Technology Ministery of Spain, year 2007, the European Commission, Marie Curie Action MEST-CT2004-513915, and project MAT2007. 63234.

\section{REFERENCES}

[1] A. Duran, J.L. Perez-Rodriguez, M.C. Jimenez de Haro, L.K. Herrera and A. Justo, J. Cult. Herit. 9 (2008) 184-188.

[2] S.E. Dunkle, Master of Science in Geological Sciences, Virginia Polytechnic Institute and State University, Blacksburg, Virginia, U.S.A., 2002.

[3] E. Rocca, C. Rapin and F. Mirambet, Corros. Sci. 46 (2004) 653-665.

[4] J. Tétrault, J. IIC-CG 17 (1992) 17-25.

[5] N.H. Tennent, J. Tate and L. Cannon, SSCR J. 4 (1993) 8-11.

[6] C. Degrigny C. Le Fall, R. Geuilmoint and E. Papers, Proc. ICOM Committee for Conservation $11^{\text {th }}$ Triennial Meeting, Edinburgh, Scotland, 1996, James \& James (Science Publishers eds.), London, England, pp. 865-870.
[7] U. Schwertmann, Neues Jb. Miner. 93 (1959) 67-86.

[8] L. Uller, H. Videla and L.K. Herrera, Proc. LatinCorr, paper nํ124, ABRACO (Eds.), Rio de Janeiro, Brasil, 2006.

[9] E. Mattson and R. Holm, Atm. Corros. (1982) 365-382.

[10] P. Eriksson, L. Johansson and J. Gullman, Corros. Sci. 34 (1993) 1083-1097.

[11] J.D. Meakin, D.L. Ames and D.A. Dolske, Atmos. Environ 26B (1992) 207-215.

[12] G. Lanterna, Thermochim. Acta 269/270 (1995) 729-742.

[13] L.S. Selwyn, N.E. Binnie, J. Poitras, M.E. Laver and D.A. Dowham, Stud. Conserv. 41 (1996) 205-228.

[14] F. Morser, The glass industry 42 (1961) 244-286.

[15] P. Hadsund, Stud. Conserv 38 (1993) 3-16.

[16] A. Kossolapov and J. Twilley, Stud. Conserv. 39 (1994) 257-264.

[17] P. Hadsund, The Art Bulletin 80, (1998) 138 171.

[18] D.A. Scott, Metallography and microstructure of ancient and historic metals, J. Paul Getty Conservation Institute and J. Paul Getty Museum (eds.), Malibu, California, U.S.A., 1991, p. 176.

[19] L.K. Herrera, A. Duran, M.C. Jiménez de Haro, J.L. Perez-Rodriguez and A. Justo, Coalition Electronic Newsletter 14 (2007) 10-14.

[20] M. Lewin and E. Pearce (Eds.), Handbook of fiber chemistry ( $2^{\text {nd }}$ Edition), International Fiber Science and Technology Series / 15, Marcel Dekker, Inc. New York, U.S.A. 1998, pp. 577 725.

[21] A. Duran, Unpublished Ph. D., Metodologia de estudio y análisis de diferentes tipos de obras de arte pertenecientes a los siglos XVII y XVIII, Univ. Seville, Spain, 2006.

[22] C. Hall and M. Davies, Identification of textile materials $\left(3^{\circ} \mathrm{Ed}.\right)$, Ed. Textile Institute, Manchester, England, 1951, p.220

[23] J. M. Cronyn, The Elements of Archaeological Conservation, Ed. Routledge, London, England, 1990, p. 352.

[24] S. Turgoose, Lead and tin studies in conservation and technology, C.E. Miles and S.C. Pollard (Eds.), UKIC Occassional Papers, no 3, London, England, 1985, pp. 15-26.

[25] P.D. Donovan and J, Stringer, Proc. of the $4^{\text {th }}$ International Congress on Metallic Corrosion, 1972, N.E. Hammer (ed.), National Association of Corrosion Engineers, Houston, U.S.A., pp. 537-543. 
[26] S. Bradley and D. Thickett, Proc. ICOM Committee for Conservation $12^{\text {th }}$ Triennial Meeting, Lyon, France, 1999, James \& James (Science Publishers eds.), London, England, pp. 8-13.

[27] M.R. Raychaudhuri and P. Brimblecombe, Stud. Conserv. 45 (2000) 226-232.

[28] S. Reguer, P. Dillmann and F. Mirambet, Corros. Sci. 49 (2007) 2726-2744

[29] A. Duran, J.L. Perez-Rodriguez, L.K. Herrera, M.C. Jiménez de Haro, M.D. Robador, A. Justo, J.M. Blanes and J.C. Perez-Ferrer, Rev. Metal. Madrid 44 (2008) 85-91.

[30] D. Neff, L. Bellot-Gurlet, P. Dillmann, S. Reguer and L. Legrand, J. Raman Spectrosc. 37 (2006) 1228-1237.

[31] S. Réguer, D. Neff, L. Bellot-Gurlet and P. Dillmann, J. Raman Spectrosc. 38 (2004) 389-397.

[32] M.C. Jiménez de Haro, A. Justo, A. Duran, M.B. Sigüenza and J.L. Perez-Rodriguez, Air
Pollution and Cultural Heritage, C. Saiz (ed.), Balkema Publishers, London, England, 2004, pp. 79-84.

[33] W.A. Oddy and N.D. Meeks, Science and technology in the service of conservation, N.S. Bromelle and G. Thompson (eds.), International Institute for Conservation of Historic and Artistic Works, London, England, 1982, pp. 119. 124.

[34] M. P. E. Berthelot, Ann. Chim. Phys. 7 (1895) 546-574.

[35] D.A. Scott, J. Am. Inst. Conserv.29 (1990) 193206.

[36] W.A. Oddy and M.J. Hughes, Stud. Conserv. 15 (1970) 183-189.

[37] J.B. Sharkey and S.Z. Lewin, Am. Mineral. 56 (1971) 179-192

[38] L.K. Herrera, A. Duran, M.L Franquelo, M.C. Jimenez de Haro, A. Justo and J.L PerezRodriguez, J. Cult. Herit. 9 (2008) e41-e46. 